\title{
Tetherin antagonism by HIV-1 and its SIV precursors
}

\author{
Frank Kirchhoff \\ From Frontiers of Retrovirology 2011 \\ Amsterdam, The Netherlands. 3-5 October 2011
}

Retroviruses have evolved effective strategies to evade the host immune response, such as high variability and latent infection. In addition, primate lentiviruses, such as HIV-1, have acquired several «accessory» genes that antagonize antiviral host restriction factors and facilitate viral immune evasion, thereby allowing continuous and efficient viral replication despite apparently strong innate and acquired immune responses. Here, I summarize some of our current knowledge on the function of the viral $v p u$ and nef genes, with a particular focus on their capability to antagonize an antiviral factor named "tetherin" (BST-2) that tethers nascent virions at the cell surface. Evidence will be presented that switches between Nef- and Vpu-mediated tetherin antagonism preceded the emergence of HIV-1. Furthermore, it will be discussed why tetherin most likely poses a significant hurdle to cross-species transmissions of simian immunodeficiency viruses to humans. To our current knowledge only pandemic HIV-1 M (major) strains mastered this barrier perfectly by,,regaining" efficient tetherin activity by $\mathrm{Vpu}$ following the four independent crossspecies transmissions that resulted in HIV-1 groups $M$, $\mathrm{O}, \mathrm{N}$, and $\mathrm{P}$. This may potentially explain why HIV-1 $\mathrm{M}$ it is almost entirely responsible for the HIV/AIDS pandemic.

Published: 3 October 2011

doi:10.1186/1742-4690-8-S2-08

Cite this article as: Kirchhoff: Tetherin antagonism by HIV-1 and its SIV precursors. Retrovirology 2011 8(Suppl 2):O8.

Submit your next manuscript to BioMed Central and take full advantage of:

- Convenient online submission

- Thorough peer review

- No space constraints or color figure charges

- Immediate publication on acceptance

- Inclusion in PubMed, CAS, Scopus and Google Scholar

- Research which is freely available for redistribution

\section{() Biomed Central}

\section{Ciomed Central}

